\title{
Front Matter: Volume 10713
}

, "Front Matter: Volume 10713," Proc. SPIE 10713, Pacific-Rim Laser Damage 2018: Optical Materials for High-Power Lasers, 1071301 (31 July 2018); doi: 10.1117/12.2502057

SPIE Event: Pacific Rim Laser Damage 2018: Optical Materials for High Power SPIE. Lasers, 2018, Yokohama, Japan 


\title{
PROCEEDINGS OF SPIE
}

\section{Pacific-Rim Laser Damage 2018 \\ Optical Materials for High-Power Lasers}

\author{
Takahisa Jitsuno \\ Jianda Shao \\ Wolfgang Rudolph \\ Editors
}

\section{4-27 April 2018 \\ Yokohama, Japan}

Sponsored by

SPIE

Organized by

Institute of Laser Engineering, Osaka University (Japan)

SIOM-Shanghai Institute of Optics and Fine Mechanics (China)

Cooperating Organizations

Institute for Laser Technology (Japan)

Laser Society of Japan

Japan Laser Processing Society

Published by

SPIE 
The papers in this volume were part of the technical conference cited on the cover and title page. Papers were selected and subject to review by the editors and conference program committee. Some conference presentations may not be available for publication. Additional papers and presentation recordings may be available online in the SPIE Digital Library at SPIEDigitalLibrary.org.

The papers reflect the work and thoughts of the authors and are published herein as submitted. The publisher is not responsible for the validity of the information or for any outcomes resulting from reliance thereon.

Please use the following format to cite material from these proceedings:

Author(s), "Title of Paper," in Pacific-Rim Laser Damage 2018: Optical Materials for High-Power Lasers, edited by Takahisa Jitsuno, Jianda Shao, Wolfgang Rudolph, Proceedings of SPIE Vol. 10713 (SPIE, Bellingham, WA, 2018) Seven-digit Article CID Number.

ISSN: 0277-786X

ISSN: 1996-756X (electronic)

ISBN: 9781510619920

ISBN: 9781510619937 (electronic)

Published by

SPIE

P.O. Box 10, Bellingham, Washington 98227-0010 USA

Telephone +1 3606763290 (Pacific Time) · Fax +1 3606471445

SPIE.org

Copyright @ 2018 , Society of Photo-Optical Instrumentation Engineers.

Copying of material in this book for internal or personal use, or for the internal or personal use of specific clients, beyond the fair use provisions granted by the U.S. Copyright Law is authorized by SPIE subject to payment of copying fees. The Transactional Reporting Service base fee for this volume is $\$ 18.00$ per article (or portion thereof), which should be paid directly to the Copyright Clearance Center (CCC), 222 Rosewood Drive, Danvers, MA 01923. Payment may also be made electronically through CCC Online at copyright.com. Other copying for republication, resale, advertising or promotion, or any form of systematic or multiple reproduction of any material in this book is prohibited except with permission in writing from the publisher. The CCC fee code is 0277$786 \mathrm{X} / 18 / \$ 18.00$.

Printed in the United States of America.

Publication of record for individual papers is online in the SPIE Digital Library.

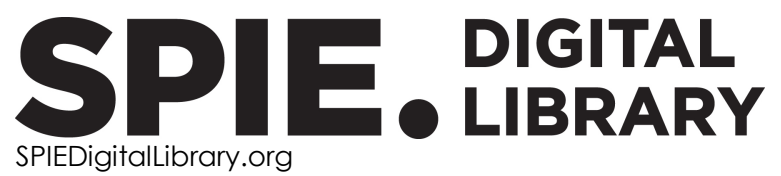

Paper Numbering: Proceedings of SPIE follow an e-First publication model. A unique citation identifier (CID) number is assigned to each article at the time of publication. Utilization of CIDs allows articles to be fully citable as soon as they are published online, and connects the same identifier to all online and print versions of the publication. SPIE uses a seven-digit CID article numbering system structured as follows:

- The first five digits correspond to the SPIE volume number.

- The last two digits indicate publication order within the volume using a Base 36 numbering system employing both numerals and letters. These two-number sets start with $00,01,02,03,04$, 05, 06, 07, 08, 09, OA, OB ... OZ, followed by 10-1Z, 20-2Z, etc. The CID Number appears on each page of the manuscript. 


\title{
Contents
}

\author{
$\checkmark \quad$ Authors \\ vii Conference Committee \\ ix Introduction
}

SLPC-PLD-LIC1: JOINT SESSION II

1071303 UV-induced aging leading to laser damage in the bulk of fused silica (Invited Paper) [10713-2]

HIGH-POWER LASER DAMAGE I

1071304 Toward "defect-free" optics: a pioneering comprehensive metrology method (Invited Paper) [10713-3]

1071306 Comparison of 355-nm nanosecond and 1064-nm picosecond laser induced damage in highreflective coatings [10713-5]

HIGH-POWER LASER DAMAGE II

1071309 Effect of micro-crack and reaction product on laser damage performance of optical glass during chemical etching [10713-8]

$10713 \mathrm{OA}$ Strategies for improving the laser-induced damage thresholds of dichroic coatings developed for high-transmission at $527 \mathrm{~nm}$ and high reflection at $1054 \mathrm{~nm}$ [10713-9]

$10713 \mathrm{OB} \quad$ Improving the environmental stability of e-beam coatings by employing a PIAD capping layer (Invited Paper) [10713-10]

DEFECTS AND DUV

$10713 \mathrm{OF}$ Transmissivity testing of calcium fluoride windows under high pulse repetition rate laser irradiation at $193 \mathrm{~nm}$ [10713-14]

LASER MATERIALS

$107130 \mathrm{~J} \quad \mathrm{Highly}$ efficient $\mathrm{Ho}: \mathrm{KY}\left(\mathrm{WO}_{4}\right)_{2}$ thin-disk lasers at $2.06 \mu \mathrm{m}$ (Invited Paper) [10713-18] 
SHORT-PULSE LASERS

10713 OU Laser damage metrology in the sub-ps range for the PETAL facility (Invited Paper) [10713-29]

$107130 \mathrm{~W} \quad$ Generation of few-cycle millijoule pulses at $5 \mu \mathrm{m}$ employing a ZnGeP2-based OPCPA pumped with GW peak power pulses at $2 \mu \mathrm{m}$ (Invited Paper) [10713-31]

DAMAGE MEASUREMENT AND DEFECTS

1071311 Shape dependence of downstream light intensification caused by flaws [10713-37]

1071312 Combined modulation to incident laser by subsurface crack and contaminant on fused silica [10713-38]

\section{POSTER SESSION}

$107131 \mathrm{~F} \quad$ Non-invasive and in situ measurement of a refractive index gradient profile of one-dimensional GRIN materials [10713-51]

$107131 \mathrm{M}$ Quasi-CW laser-induced damage of indium tin oxide films and polyimide films at $1064 \mathrm{~nm}$ wavelength [10713-58] 


\section{Authors}

Numbers in the index correspond to the last two digits of the seven-digit citation identifier (CID) article numbering system used in Proceedings of SPIE. The first five digits reflect the volume number. Base 36 numbering is employed for the last two digits and indicates the order of articles within the volume. Numbers start with 00, 01, 02, 03, 04, 05, 06, 07, 08, 09, OA, OB...0Z, followed by 10-1Z, 20-2Z, etc.

Aguiló, Magdalena, $0 \mathrm{~J}$

Beaudier, Alexandre, 03

Bock, Martin, OW

Cao, Zhaoliang, $1 \mathrm{M}$

Chai, Yingjie, OB

Chen, Jian, 04

Chen, Zhi, 09, 12

Cui, Yun, 06

Díaz, Francesc, 0J

Elsaesser, Thomas, OW

Fan, Yuanyuan, OF

Field, Ella S., OA

Fuhrberg, Peter, OJ

Gallais, Laurent, OU

Griebner, Uwe, 0J, OW

Guina, Mircea, 0J

Guo, Yajing, 11

Härkönen, Antti, OJ

Huang, Ming, 04

Jiang, R., OF

Jiao, Zhaoyang, 11

Kletecka, Damon E., OA

Lamaignère, Laurent, $\mathrm{OU}$

Lamrini, Samir, OJ

Lavastre, Eric, OU

Li, Cheng, 06

Li, Hui, OF

Li, Wencai, 04

Liang, Rongguang, 09, 12

Liu, Huasong, OB

Liu, Shijie, 04

Liu, Xiaofeng, 1M

Liu, Yonggang, $1 \mathrm{M}$

Loiko, Pavel, OJ

Ma, Liang, 04

Mateos, Xavier, OJ

Nasibov, H., IF

Natoli, Jean-Yves, 03

Néauport, Jérôme, OU

$\mathrm{Ni}$, Kaizao, 04

Peng, Liping, $1 \mathrm{M}$

Peng, Xiaocong, 06

Petrov, Valentin, 0J

Ren, Lei, 11

Roquin, Nadja, OU

Scholle, Karsten, 0J

Sha, Pengfei, OF

Shan, Chong, 06

Shao, Jianda, 04, 06, OB, 1M
Song, Xingliang, OF

Sozet, Martin, OU

Sun, Mingying, 11

Suomalainen, Soile, $0 \mathrm{~J}$

Vatnik, Sergei, 0J

Vedin, Ivan, OJ

von Grafenstein, Lorenz, OW

Wagner, Frank R., 03

Wang, Hairong, 09, 12

Wang, Jianguo, 06

Wang, Jiuhong, 09, 12

Wang, Yicheng, OJ

Wang, Yu, OF

Wu, Rong, 11

Xiao, Huapan, 09, 12

Xiong, Guangliang, OF

$\mathrm{Xu}, \mathrm{N} \cup \mathrm{O}, \mathrm{OB}$

Yang, Junhong, OF

Yin, Chaoyi, OB

Yu, Na, 09, 12

Zeng, Tingting, $O B$

Zhang, Rongjun, $\mathrm{OB}$

Zhang, Yanli, 11

Zhao, Jiangshan, OF

Zhao, Yuan'an, 04, 06, $1 \mathrm{M}$

Zhou, Yi, OF

Zhu, Jianqiang, 11

Zhu, Meiping, 04, 06, 0B, 1M

Zong, Huiwen, OF 
Proc. of SPIE Vol. 10713 1071301-6

Downloaded From: https://www.spiedigitallibrary.org/conference-proceedings-of-spie on 25 Apr 2023 Terms of Use: https://www.spiedigitallibrary.org/terms-of-use 


\title{
Conference Committee
}

\author{
Conference Chairs
}

Takahisa Jitsuno, Osaka University (Japan)

Jianda Shao, Shanghai Institute of Optics and Fine Mechanics

(China)

Wolfgang Rudolph, The University of New Mexico (United States)

Conference Program Committee

Efim A. Khazanov, Institute of Applied Physics (Russian Federation)

Zhi M. Liao, Lawrence Livermore National Laboratory (United States)

Zunqi Lin, Shanghai Institute of Optics and Fine Mechanics (China)

Yongfeng Lu, University of Nebraska-Lincoln (United States)

Jean-Yves Natoli, Institut Fresnel (France)

Valdas Sirutkaitis, Vilnius University (Lithuania)

MJ Soileau, CREOL, The College of Optics and Photonics, University of

Central Florida (United States)

Koji Sugioka, RIKEN (Japan)

Takunori Taira, Institute for Molecular Science (Japan)

Mauro Tonelli, Università di Pisa (Italy)

Zhouling Wu, ZC Optoelectronic Technologies Ltd. (China)

Qiao Xu, China Academy of Engineering Physics (China)

Jiping Zou, École Polytechnique (France)

Session Chairs

SLPC-PLS-LIC 1: Joint Session I

Kunihiko Washio, Paradigm Laser Research Ltd. (Japan)

Takahisa Jitsuno, Osaka University (Japan)

SLPC-PLD-LIC 1: Joint Session II

Takahisa Jitsuno, Osaka University (Japan)

High-power Laser Damage I

Takahisa Jitsuno, Osaka University (Japan)

High-power Laser Damage II

Zhouling Wu, ZC Optoelectronic Technologies Ltd. (China)

Defects and DUV

Stavros G. Demos, University of Rochester (United States) 
Laser Materials

Takahisa Jitsuno, Osaka University (Japan)

Etching and Non-linear Crystals

Tomosumi Kamimura, Osaka Institute of Technology (Japan)

Short-pulse Lasers

Shinji Motokoshi, Institute for Laser Technology (Japan)

Damage Measurement and Defects

Takahisa Jitsuno, Osaka University (Japan) 


\section{Introduction}

As a part of Optics and Photonics International Congress (OPIC), we organized the 8th Pacific-rim Laser Damage conference 2018 (PLD 2018), in Yokohama, Japan, 24-27 April 2018. This conference was co-sponsored by SPIE and Shanghai Institute of Optics and Fine Mechanics (SIOM) in China. The PLD conference was started in 2009, by Prof. Jianda Shao, at SIOM, as a satellite meeting of the SPIE Laser Damage conference in Boulder, Colorado (United States), a conference with a 48-year history. The PLD meeting is held bi-yearly in Shanghai, China, and PLD 2014, PLD 2016, and PLD 2018 were held in Yokohama. At the first PLD conference, Dr. K. Sugioka of Riken served as the co-chair from Japan. I joined at the second meeting in 2011, in response to a request from Prof. J. Shao, and since the third meeting in 2013, I have acted as the co-chair of the conference. The fourth and sixth PLD meetings were held in Yokohama, in 2014 and 2016, as a part of the OPIC conference at the recommendation of Prof. J. Shao.

As with other PLD meetings, this conference was co-chaired by Prof. J. Shao and Prof. W. Rudolph. The international program committee of PLD 2018 had almost the same members as PLD 2017, and we also invited a member from Japan for the organizing committee.

\section{Joint session with LIC, SLPC conferences}

At this conference, we organized joint sessions with the Laser lgnition conference (LIC2018) and Smart Laser Process conference (SLPC2018) because these conferences have a common interest with the interaction of laser light and matter. The PLD, LIC, and SLPC conferences each nominated two invited talks, and we had two joint sessions on 25 April 2018.

Two of the invited talks from PLD were presented in the joint sessions. "Mechanisms of laser damage in optical components for PW-class laser systems," was reported by Stavros G. Demos, LLE, University of Rochester (United States) [10713-1]. "UVinduced aging leading to laser damage in the bulk of fused silica," was presented by Frank R. Wagner, Institute of Fresnel (France) [10713-2].

\section{Oral and Invited talks}

We had a total of ten sessions including the poster session. We selected ten invited talks according to the recommendations of program committee members. One of them was the plenary talk for PLD 2018 from SIOM, reporting on defect-free optics [10713-3]. This talk was planned as Prof. J. Shao's talk, but unfortunately, he could not attend the conference.

In the other seven invited talks, selected speakers from seven countries reported on the progress and results of their research. 


\section{Poster session}

In the poster session, 14 reports were presented concerning resist removal, the fundamental process of metal processing, the semiconductor process, the nonlinear crystal growth, and the anti-reflection nano-structure.

\section{Contributions}

40 papers were presented at the meeting. The ratio of international papers was $85 \%$, and international attendance was $78 \%$ because of the small domestic population of research activity in Japan.

The contributed papers were from China (23), United States (2), Japan (6), France (2), Germany (2), and the United Kingdom, Russia, Turkey, Egypt, and Romania (1, each) respectively.

\section{Conclusions}

PLD 2018 was held as a part of the OPIC conferences in Yokohama, Japan. This system is very effective in supporting small international conferences, which is difficult to achieve alone. The Chairs wish to express deep thanks to the organizing members of OPIC and SPIE for the success of PLD 2018.

\section{Takahisa Jitsuno}
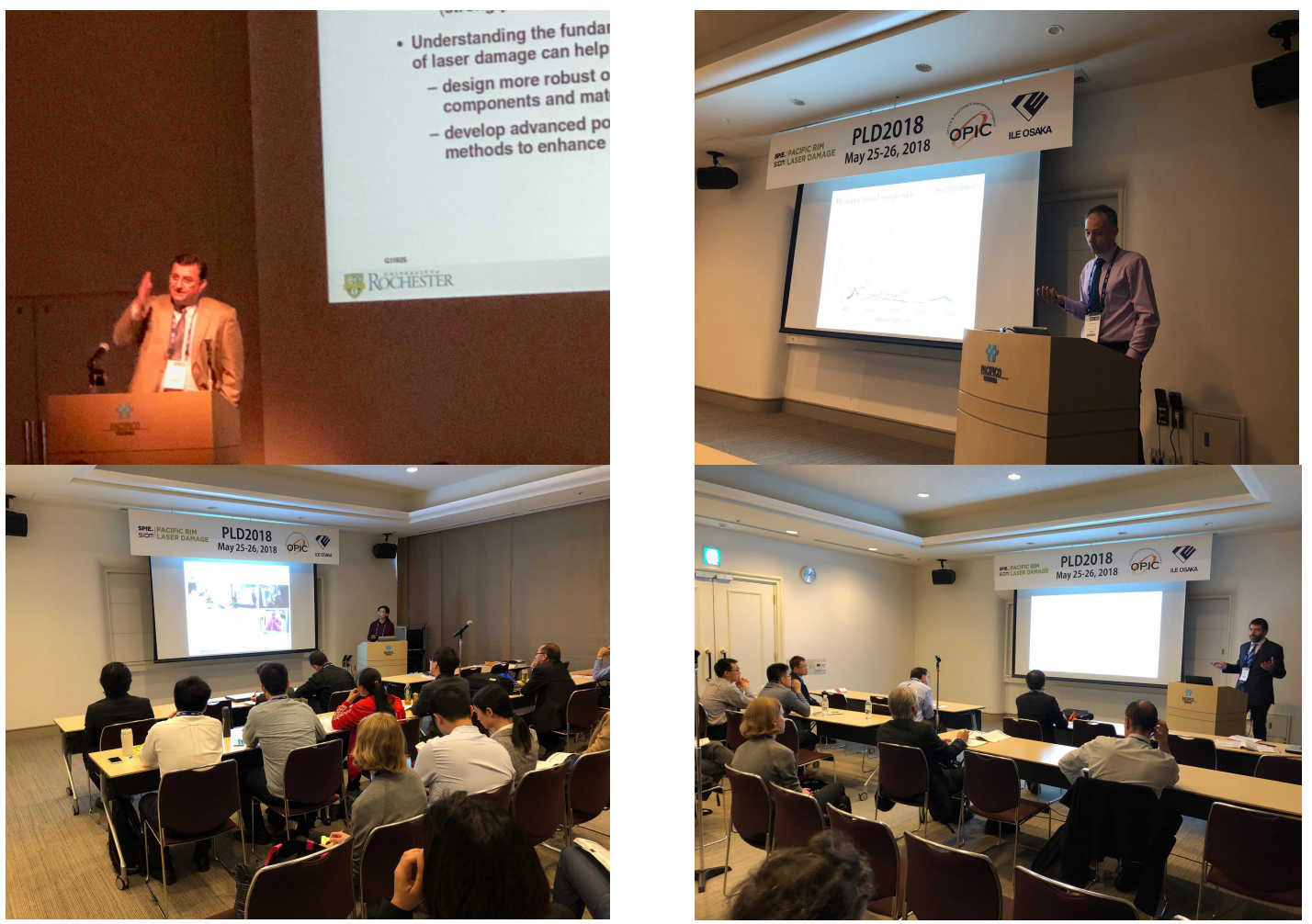